\title{
STOP 7: Madona-Trepe ice-marginal ridge at Smeceres sils, East-Latvian Lowland
}

Vitālijs Zelčs, Māris Krievāns and Māris Nartišs

University of Latvia

The Madona-Trepe ice-marginal ridge (Fig. 7.1) is the most prominent ice-marginal formation in Latvia. This spectacular moraine ridge, generally oblique to streamlined landforms (megaflutes to mega-lineations), marks the maximum extent of the Lubāns ice lobe during the Gulbene deglacilation phase in the East-Latvian Lowland (Meirons et al. 1976; Zelčs and Markots 2004; Zelčs et al. 2011).

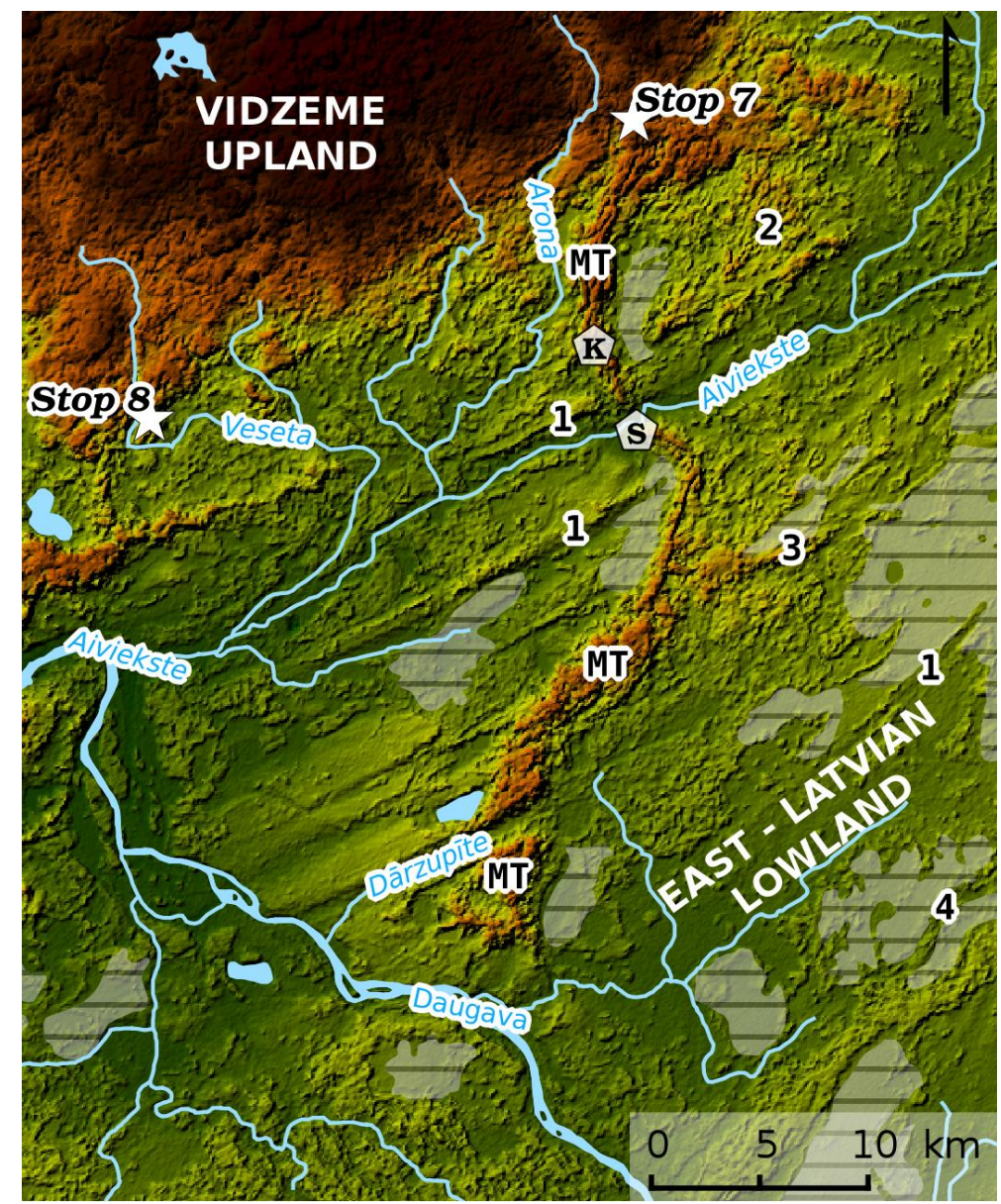

Fig. 7.1. SRTM DEM of the glacial terrain along the Madona-Trepe ice-marginal ridge. Note that megaflutes and megascale lineations are superimposed by small recessional moraine ridges. Legend: MT - Madona-Trepe ridge; K - Krustkalni gravel pit; S - Sāviena gravel pit; 1 - megaflutes and megascale lineations; 2 - hummocky topography; 3 - lateral shear marginal moraine; 4 - esker.

The Madona-Trepe ridge stretches for a distance of $45 \mathrm{~km}$ between the east-Latvian stretch of the River Daugava valley and the outer slope of the Vidzeme Upland, associated with a belt of lateral moraine ridges (so-called oriented marginal relief of the peripheral zone after Āboltiņš et al. 1975; Āboltinšs 1995) modified by meltwater discharge. Deeply incised transverse meltwater drainage channels, probably tunnel valleys, maintained nowadays by the Rivers Aiviekste and Dārzupite, and the dry valley next to Stop 7 at Smeceres sils (2609'54"E, 56 49'39"N), split the Madona-Trepe ridge into four parts. On both sides of the dry valley the highest points of the surface topography slightly exceed $170 \mathrm{~m}$ a.s.l. and rise 
almost $70 \mathrm{~m}$ above proximal ice-scooped basins occupied by lakes and mires, a distally located ice-marginal drainage channel and large glaciokarst kettles. The elevation and local relief fall away in the direction of the River Daugava valley, i.e. the centre line of the ice lobe terminus. The width of the Madona-Trepe ridge varies from $0.7 \mathrm{~km}$ to $5 \mathrm{~km}$. South of the dry valley its surface is undulated by $2-50 \mathrm{~m}$ high, subparallel or parallel elongated ramparts. Their roughly NNE-SSW strike corresponds to the general orientation of the ice-marginal ridge.

The Madona-Trepe ice-marginal ridge is situated on an elongated bedrock rise. It lies about $80 \mathrm{~m}$ a.s.l. in its more elevated part, and gradually lowers to $50 \mathrm{~m}$ a.s.l. in the direction of the centre line of the Lubāns lobe terminus. The bedrock consists of Upper Devonian terrigenous deposits, but $\mathrm{S}$ of the dry valley these are replaced by carbonate rocks. The complex of Weichselian sediments, mainly waterlain, that overlies the bedrock, is $80-90 \mathrm{~m}$ thick in the morphologically more expressed part, thinning towards the SSW to $40-50 \mathrm{~m}$. Here it is at least twice or up to four times thicker than in the adjoining proximally located ice-scooped basins and glacially megalineated terrain.

The internal structure has been examined in several gravel quarries located in different parts of the ice-marginal ridge. There is no substantial difference in lithological composition between these parts of the ridge, but they differ greatly in their internal architecture, as explained below.

The coarse material (gravel, gravel and pebbles with sand), which forms most of the exposed sequence, is underlain by thinly laminated sandy sediments, which make up the lowermost part of the exposed sections. In places the coarse sediments are interlayered with sand up to 2-3 m thick, with intercalations of finer material (Fig. 7.2: I) and containing occasional gravel and dispersed small pebbles in the lower part of the interlayer. The laminated sandy sediments also occur in an enormous area along both sides of the Madona-Trepe ridge, also

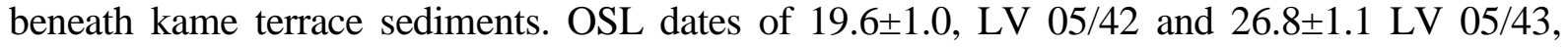
obtained from the interlayer of sand (Fig. 7.2: II) in the Smeceres sils quarry, suggest that they were most probably deposited slightly before and/or during the maximum transgression of the Late Weichselian glaciation in this area (Raukas et al. 2010). However, the burial OSL age of the thinly laminated sand deposited in the lower part of two other sections $(46.0 \pm 8.6 ; 41.4 \pm 8.6$; $49 \pm 22$; due to very wide paleodose distributions, the results should be considered only as age estimates), located in a small ice-pushed ridge and lateral shear moraine moraine, yield evidence of deposition during the Middle-Weichselian interstadial.

Four recently studied sections (Fig. 7.2), situated at levels from $169 \mathrm{~m}$ a.s.1. to $153 \mathrm{~m}$ a.s.l. in the gravel quarry at the Smeceres sils, reveal the internal structure of the northern stretch of the Madona-Trepe ice-marginal ridge. In general, the internal structure of the ridge has been altered only by limited glaciotectonic deformation and by mass sliding and flowage, which is encountered on the ENE slope (Fig. 7.2: IV). Coarsening upwards of the coarse sequence (Fig. 7.2: I) can be explained by the acceleration of ice melt, resulting in boulder concentration, in some cases also in the formation of a boulder pavement on the topmost part, and in the appearance of scattered boulders on the distal slope of the ice-marginal ridge. Besides this, cobbles and boulders have been altered to some extent by frost weathering and covered by coversand. The upper coarse sequence rests on up to 2-3 m thick, predominantly medium- to fine-grained sand with intercalations of silt and clay strings (Fig. 7.2: II). The sand has been OSL dated (Raukas et al. 2010). The underlying gravel bed is interlayered with sand, which contains occasional gravel strings and dispersed small pebbles (Fig. 7.2: III). According to bedding plane measurement data, it is more likely that the exposed sediments represent icemarginal fan deposition. The ridge slope consists of supraglacial melt-out and gravity flow till in places with lenses of meltwater sediments underlain by laminated sand (Fig. 7.2: IV). 

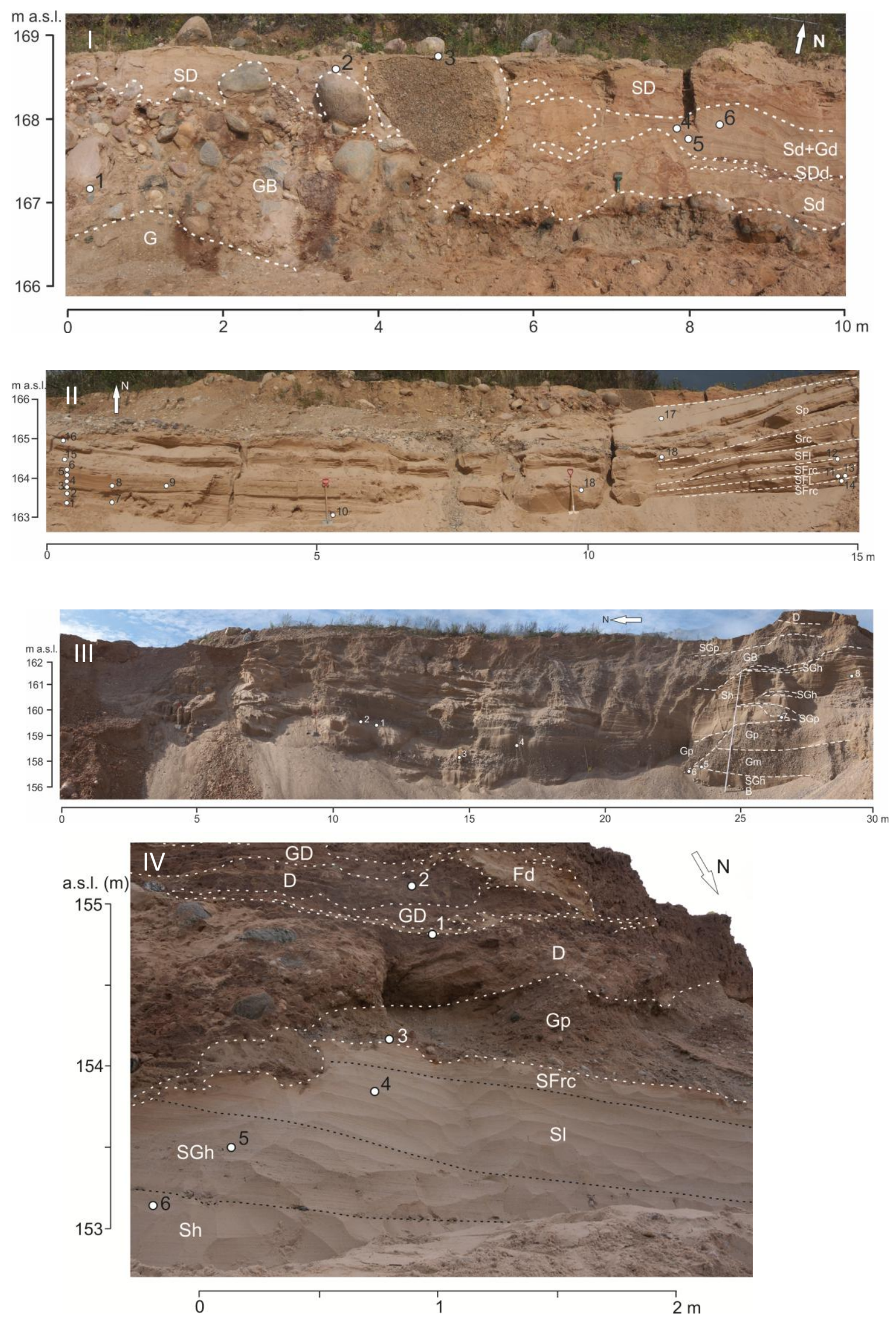

Fig. 7.2. Internal structure of the Madona-Trepe ice-marginal ridge at Smeceres sils in the exposures of the gravel pit located next to the dry meltwater discharge valley. Note that the sections are located at different elevation. White dots and numbers denote measurement sites of the bedding planes and glacial striation; D diamicton; B - boulders; G - gravel; Gd - deformed gravel; $\mathrm{Gm}$ - massive gravel; $\mathrm{Gp}$ - planar cross-stratified gravel; GD - diamictic gravel; GB - bouldery gravel; Sd - deformed sand; Sh - horizontally bedded sand; Sl - 
low-angle cross-bedded sand; Sp - planar cross-bedded sand; Src - subcritically climbing-ripple cross-laminated sand; SD - diamictic sand; SDd - deformed diamictic sand; SGh - horizontally bedded gravelly sand; SGp planar cross-stratified gravelly sand; SFl - low-angle cross-bedded sand with fines; SFrc - climbing ripple crosslaminated sand with fines; Fd - deformed silt. I. Gravel with cobbles and boulders altered to some extent by frost weathering, underlain by gravel with dispersed pebbles and covered by coversand; II. Up to $2-3 \mathrm{~m}$ thick, predominantly medium- to fine-grained sand with intercalations of silt and clay strings, OSL dated (Raukas et al. 2010); III. Gravel interlayered with sand, containing occasional gravel strings in some interlayers; IV. Supraglacial melt-out and gravity flow till in places with lenses of meltwater sediments underlain by the laminated sand.

The internal structure reveals that between the dry valley at Smeceres sils and the River Aiviekste valley recessional megablock and thrusted scale sheets are dominant. These glaciotectonic deformation structures mainly consist of gravel with an admixture of pebbles, gravel with sand, and occasional interlayers of gravelly sand. Common south of the River Aiviekste valley up to the Dārzupîte are large inclined and overturned folds, fold-faults and overthrusts with plastering of till on the upglacier side. These differences in internal structure, their spatial succession and the morphological peculiarities of the distinct parts of the Madona-Trepe ice-marginal ridge, in the light of the recent studies done by Evans et al. (2008, 2014) and Krüger et al. (2010), suggest quite different circumstances along the terminus of the Lubāns lobe during the Gulbene oscillation phase. In the segments of glacial recession glaciotectonic shortening prevailed due to compressive ice basal motion, while along the centre line of the ice lobe terminus the glacier has overridden smoothed and, possibly, buried push moraines.

The topography of the Madona-Trepe ridge and the terrain beyond and behind it resembles to a great extent the Wolf Lake vicinity, Alberta, described by Andriashek and Fenton (1989). Besides, as seen in Fig. 7.1, the Madona-Trepe ridge is curved, forming arcuate clusters. This morpholological feature indicates differentiation of the ice basal marginward motion in the transverse section of the Lubāns lobe in a similar manner to that suggested by Stephan (1985: Fig. 3) in a block movement model for glacier pushing. Lowering and widening of the ridge, and thinning of the landforming sediments in the direction of the centre line of the Lubāns lobe terminus can be explained by the mechanism noted by Krüger et al. (2010). They report (ibid.), that "the most prominent ice-marginal ridges under formation were seen where the advancing glacier pushed against a rather thick body of hochsander fan deposits or a frontal ramp of mass-movement deposits. Where the glacier overrode ground moraine, the ice-marginal ridge was commonly small, probably because the glacier toe, when overriding ground moraine, was almost at the same level as the till surface beyond." Taking into account that in the case under consideration stratified gravelly sediments form a thick body and occur in a vast area on the upglacier and downglacier sides of the Madona-Trepe ice marginal ridge, they have been interpreted as most probably constituting outwash (excluding the part $\mathrm{N}$ of the dry valley).

\section{References}

Āboltiňš, O. 1995. Vidzeme Highland. In: Schirmer (ed.), INQUA 1995. Quaternary field trips in Central Europe. C-3 Baltic Traverse. Verlag Dr. Friedrich Pfeil, Munchen, Germany, pp. 159-162.

Āboltiňš, O., Straume, J., Juškevičs, V. 1975. Relief peculiarities and main stages of morphogenesis of Central Vidzeme Upland. In Danilāns, I. (ed.), Problems of Quaternary Geology, 8, Zinātne, Rīga, pp. 31-47 (in Russian, with English summary).

Andriashek, L.D., Fenton, M.M. 1989. Quaternary stratigraphy and surficial geology, Sand River Map Sheet 73L, Alberta. Bulletin, 057. Alberta Research Council and the Alberta Geological Survey and Terrain Sciences Department. Edmonton AB, 165 pp.

Evans, D.J.A., Clark C.D., Rea, B.R. 2008. Landform and sediment imprints of fast glacier flow in the southwest Laurentide Ice Sheet. Journal of Quaternary Science, 23(3), 149-272. 
Evans, D.J.A., Young, N.J.P., Ó Cofaigh, C. 2014. Glacial geomorphology of terrestrial-terminating fast flow lobes/ice stream margins in the southwest Laurentide Ice Sheet. Geomorphology, 204, 86-113.

Juškevičs, V., Skrebels, J. 2003. Quaternary deposits. In: Āboltiņš, O., Brangulis, A.J. (eds.), Geological Map of Latvia. Scale 1:200,000. Sheet 34-Jēkabpils. Sheet 24-Daugavpils. Explanatory Text and Maps. State Geological Survey, Rīga, pp. 10-29.

Krüger, J., Schomaker, A., Benediktsson, Í.Ö. 2010. Ice marginal environments: geomorphic and structural genesis of marginal moraines at Mýrdalsjökull. In: Schomaker, A., Krüger, J., Kjær, K.H. (eds.), The Mýrdalsjökull Ice Cap, Iceland. Glacial processes, sediments and landforms on an active volcano. Developments in Quaternary Sciences, 13, pp. 79-104.

Meirons, Z., Straume, J., Juškevičs, V. 1976. Main varieties of the marginal formations and deglaciation of the Last glaciation in the territory of the Latvian SSR. In Danilāns, I. (ed.), Problems of Quaternary Geology, 9. Rīga, Zinātne, pp. 50-73 (in Russian, with English summary).

Raukas, A., Stankowski ,W. T. J.; Zelčs, V., Šinkūnas, P. 2010. Chronology of the last deglaciation in the Southeastern Baltic region on the basis of recent OSL dates. Geochronometria, 36, p. 47-54.

Stephan, H.-J. 1985. Deformation striking parallel to glacier movement as a problem in reconstructing its direction. Geological Society Denmark Bulletin, 34, 47-53.

Zelčs, V., Markots, A. 2004. Deglaciation history of Latvia. In: Ehlers, J., Gibbard, P. L. (eds.), Quaternary Glaciations - Extent and Chronology. Part I: Europe. Developments in Quaternary Science, 2. Elsevier, Amsterdam, pp. 225-243.

Zelčs, V., Markots, A., Nartišs, M., Saks, T. 2011. Chapter 18: Pleistocene Glaciations in Latvia. In: Ehlers, J., Gibbard, P.L., Hughes, P.D. (eds.), Quaternary glaciations - extent and chronology. A closer look. Developments in Quaternary Science, 15. Elsevier, pp. 221-229. 

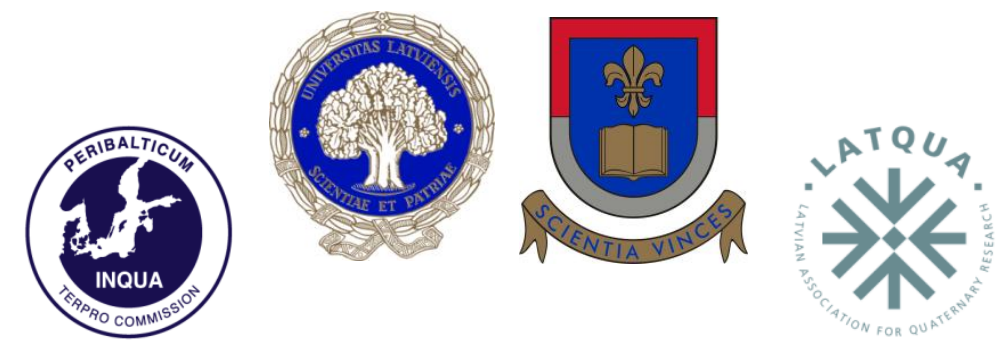

INQUA TERPRO COMMISSION PERIBALTIC WORKING GROUP

UNIVERSITY OF LATVIA

UNIVERSITY OF DAUGAVPILS

LATVIAN ASSOCIATION FOR QUATERNARY RESEARCH

\section{LATE QUATERNARY \\ TERRESTRIAL PROCESSES, SEDIMENTS AND HISTORY: FROM GLACIAL TO POSTGLACIAL ENVIRONMENTS}

EASTERN AND CENTRAL LATVIA

AUGUST 17-22, 2014 


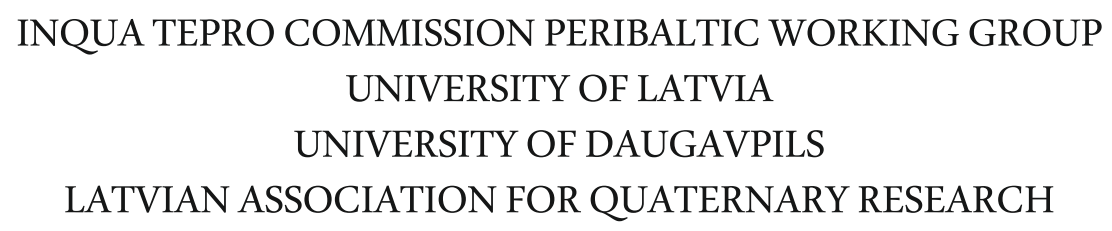

\title{
LATE QUATERNARY \\ TERRESTRIAL PROCESSES, SEDIMENTS AND HISTORY: FROM GLACIAL TO POSTGLACIAL ENVIRONMENTS
}

\author{
EASTERN AND CENTRAL LATVIA
}

AUGUST 16-22, 2014 
Organized by:

University of Latvia

Daugavpils University

Latvian Association for Quaternary Research

INQUA Peribaltic Working Group (INQUA TERPRO Commission)

Organizing committee:

Māris Nartišs (Chair, University of Latvia)

Māris Krievāns (Secretary, University of Latvia)

Aivars Markots (University of Latvia)

Juris Soms (Daugavpils University)

Evija Tērauda (University of Latvia)

Vitālijs Zelčs (University of Latvia)

Contributors:

Ivars Celiņš, Edgars Greiškalns, Ieva Grudzinska, Edyta Kalińska-Nartiša, Laimdota Kalniņa, Jānis Karušs, Māris Krievāns, Kristaps Lamsters, Aivars Markots, Māris Nartišs, Agnis Rečs, Normunds Stivriņš, Juris Soms, Ivars Strautnieks, Santa Strode, Sandra Zeimule, Vitālijs Zelčs

Editors: Vitālijs Zelčs and Māris Nartišs

The English texts of the field guide were revised by Valdis Bērziņš

Recommended reference for this publication:

Zelčs, V. and Nartišs, M. (eds.) 2014. Late Quaternary terrestrial processes, sediments and history: from glacial to postglacial environments. Excursion guide and abstracts of the INQUA Peribaltic Working Group Meeting and field excursion in Eastern and Central Latvia, August 17-22, 2014. University of Latvia, Rīga, 2014, 150 pages.

Sponsored by:

University of Latvia

Layout: Vitālijs Zelčs, Māris Nartišs and Māris Krievāns

ISBN 078-9934-517-60-0

(C) University of Latvia, 2014

This volume is available from:

Faculty of Geography and Earth Sciences

University of Latvia

Rainis Blvd. 19

Rìga, LV1586

Latvia 